\title{
West Nile Virus Seroprevalence in Horses from Romania: First Step in the Infection Risk Assessment
}

\author{
Luanda LUDU (OŞLOBANU) ${ }^{1}$, Anca PÂSLARU ${ }^{1}$, Gheorghe SAVUȚA ${ }^{1 *}$ \\ ${ }^{1}$ Department of Public Health, University of Agricultural Sciences and Veterinary Medicine Iaşi, \\ Romania \\ Corresponding author: epirovet@yahoo.com
}

Bulletin UASVM Veterinary Medicine 72(1) / 2015,

Print ISSN 1843-5270; Electronic ISSN 1843-5378

DOI:10.15835/buasvmcn-vm: 10505

\begin{abstract}
West Nile virus (WNV) infections are known to be endemic in some areas of Romania. After the last epidemics registered in 2010 in the country, it is considered that WNV has changed its patterns of evolution. The surveillance of West Nile virus includes surveillance of host species and mosquitoes vectors in order to assess the risk of WNV infection in human population. In this paper we describe the preliminary investigations made for the establishment of mosquitoes collection sites consisting in a seroepidemiological study for the detection of WNV specific antibodies made in three counties from the eastern Romania. Horse blood samples were collected from Buzău, Brăila and Tulcea Counties. From these, 60 samples were chosen randomly (at least 5 from each sampling area) and tested using a competitive ELISA. The results showed that in Tulcea and Brăila Counties WNV is enzootic. In Tulcea, high values of seroconversion were registered not only in Danube Delta (eastern part of the County), but also in the central and southern area of the county. As for Buzău County, the tested sera were negative for specific anti WNV antibodies. In Brăila and Tulcea Counties, the high rates of seroprevalence in certain areas permitted us to establish collecting sites for mosquitoes. In Buzău County West Nile virus specific antibodies were not detected until now. The collection of mosquitoes and further detection of WNV will gave us the possibility to characterize WNV circulating strains in Romania and to determine the risk areas for human infection.
\end{abstract}

Keywords: horses, risk assessment, seroprevalence, West Nile virus.

\section{INTRODUCTION}

West Nile virus (WNV) infections are known to be endemic in some areas of Romania. After the last epidemics registered in 2010 in the country, it is considered that WNV has changed its patterns of evolution (Neghina et al., 2011). The host species and WNV vectors are well documented at least in the southern area of the Romania (Nicolescu et al., 2009).

In 2010, a total of 47 human cases of West Nile virus infection were identified between July and October with a case fatality rate of $8.7 \%$. Cases were distributed in 19 counties in the southern, western, central and eastern parts of the country. This was the first time for many years when the human cases were registered in counties out of the southeastern area known as endemic (ECDC 2011).

Regarding the animals, encephalomyelitis in horses or mortality in birds due to WNV infection hasn't been reported in Romania, but data provided by the official veterinary services showed that WNV-specific antibodies were found in poultry from two counties in the eastern and western parts. WNV-specific IgG antibodies were also detected in horses from 22 counties across the country, including nine counties in which human cases of WNV infection occurred in 2010. It should be noted that IgM in horses were found in six counties: Bihor, Mures, Vrancea, Buzău, Brăila and Constanta indicating the presence of the virus in those areas in 2010 (Sîrbu et al., 2011).

During the 2010 Romanian epidemics, molecular investigation revealed that the lineage 2 related to the Volgograd 2007 strain was incriminated for the infections in human (Sîrbu et al., 2011). The WNV genome was detected in the brain tissue of one fatal human case, and in the serum and/or cerebrospinal fluid (CSF) of four of the 16 cases tested. Partial sequencing of the NS5 
gene was performed for only one positive serum sample (approximately1.200 genome equivalents/ $\mathrm{ml}$ ). Analysis of 780 nucleotides of the NS5 gene demonstrated that the virus was a WNV lineage 2 strain, with $99.3 \%$ sequence identity to the virus circulating in Volgograd in 2007 (GenBank: FJ425721.1). The surveillance system for WNV infections in humans from Romania is testing only for IgM and doesn't go forward with the viral identification or isolation. This is why data about circulating human strains are few and based on the anti WNV IgM antibodies titer in sera or CSF.

As for the vectors, studies made after the 2010 epidemics are suggesting that WNV lineage 2 strain has continued to be present in the south eastern area of Romania in 2011-2013 in Danube Delta in Mila 26 village (Dinu et al., 2013).

The surveillance of West Nile virus includes surveillance of host species and mosquito vectors in order to assess the risk of WNV infection in human population. In this paper we describe the preliminary investigations based on seroepidemiological study made in horses for the establishment of mosquito collection sites.

\section{MATERIAL AND METHODS}

A total number of 110 horse samples were collected from Buzău (n=10), Brăila $(n=40)$ and Tulcea $(n=60)$ counties (Fig.1). The sampled horses hadn't any history of travel or movement inside or out of their County of origin.

From these, 60 samples were chosen randomly (at least 5 from each sampling locality and tested using the competitive ELISA (ID Screen West Nile Competition). This test has the capacity to detect horse IgG directed against the West Nile virus envelope protein (pr-E). The IgG positive samples were tested using a kit for detection of
anti-West Nile IgM antibodies, Id Screen West Nile IgM Capture kit,that allows the detection of recent infections.

\section{RESULTS AND DISCUSSION}

From the 60 sera tested for the presence of anti WNV IgG we have found 32 positive samples corresponding to a $53.33 \%$ seroprevalence (Tab. 1). The seroprevalence in Tulcea was high $75 \%$ (24/32) meanwhile in Brăila a 40\% (8/20) seroprevalence was registered and in Buzău we haven't registered any positive samples $(0 / 8)$.

As for the detection of anti WNV IgM, from the 32 samples tested, only two were positive: one from Brăila and one from Tulcea (Carcaliu). These positive results showed us that the virus is actually circulating in those localities. Giving these results (IgM positive samples) that prove the evolution of the virus in 2013, we have established sites for the collection of mosquitoes in Brăila and Tulcea counties. Also based on previous West Nile evolution in human and high seroconvesion rates

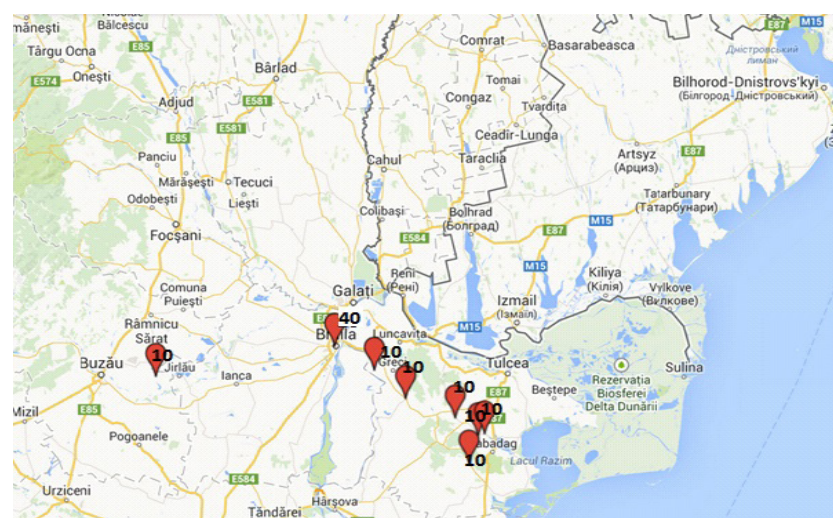

Fig.1. Sampling sites and the total number of samples collected from horses in Buzău, Brăila and Tulcea counties

Tab.1. Seropositive anti-WNV IgG horse samples

\begin{tabular}{|c|c|c|c|c|c|}
\hline Counties & Localities & $\begin{array}{c}\text { Tested } \\
\text { samples }\end{array}$ & $\begin{array}{l}\text { Positive } \\
\text { samples }\end{array}$ & $\begin{array}{l}\text { Negative } \\
\text { samples }\end{array}$ & $\begin{array}{c}\text { Seroprevalence } \\
(\%)\end{array}$ \\
\hline Brăila & Brăila & 20 & 8 & 12 & 40.00 \\
\hline \multirow{6}{*}{ Tulcea } & Slava Rusă & 5 & 4 & 1 & 80.00 \\
\hline & Carcaliu & 6 & 5 & 1 & 83.33 \\
\hline & Mihai Bravu & 5 & 3 & 2 & 60.00 \\
\hline & Iulia & 5 & 4 & 1 & 80.00 \\
\hline & Satu Nou & 5 & 4 & 1 & 80.00 \\
\hline & Cerna & 6 & 4 & 2 & 66.67 \\
\hline \multirow[t]{2}{*}{ Buzău } & Rușetu & 8 & 0 & 8 & 0.00 \\
\hline & Total & 60 & 32 & 28 & 53.33 \\
\hline
\end{tabular}


in horses (Sîrbu et al. 2011) we have chosen as collection sites Iasi and Galati counties.

\section{CONCLUSION}

It is important to establish collection sites for mosquitoes and to determine to which lineage WNV strains circulating in Romania belong. A genetic characterization should explain the lack of neurological manifestations in horses and of mortality in birds and clarify if those are really particularities of WNV infections in Romania or a surveillance artefact.

It is known that in Romania, the Danube Delta area, the south eastern counties, and at least Iasi and Galati counties from the eastern area represent risk zones for WNV transmission to humans.

In Brăila and Tulcea, the high rates of seroprevalence and the IgM presence in certain areas gave us indications for the establishment of collecting sites for mosquitoes. In Buzău County, West Nile virus specific antibodies were not detected but these do not exclude the presence of WNV.

The collection of mosquitoes and further detection of WNV should give us the possibility to characterize WNV circulating strains in Romania and to determine the risk areas for human infection.

\section{REFERENCES}

1. Dinu S, Cotar A, Gatej R, Prioteasa L, Falcuta E, Oprisan G, Badescu D, Ceianu C (2013). West Nile virus -genetic lineage 2 in the southeastern of Romania in 2011-2013. Annual conference of the Microbiology Society Bucharest (published in Romanian).

2. European Centre for Disease Prevention and Control/ WHO Regional Office for Europe, (2011).West Nile virus infection outbreak in humans in Romania, 2010, Stockholm:ECDC.

3. Neghina AM, Neghina R (2011). Reemergence of human infections with West Nile virus in Romania, 2010: an epidemiological study and brief review of the past situation.Vector Borne Zoonotic Dis 2011 Sep 11(9):128992.

4. Nicolescu G, Purcarea-Ciulacu V, Prioteasa L, Vladimirescu A, Falcuta E, Coipan EC, Dumitrescu G, Popescu D, Ionescu L, Bicheru S, Kiss JB, Marinov M, Alexse A (2009). West Nile virus in Romania. EDEN Annual Meeting, Marrakech, Morroco.

5. Sîrbu A, Ceianu CS, Panculescu-Gatej RI, Vázquez A, Tenorio A, RebreanuR, Niedrig M, Nicolescu G, Pistol A. (2011). Outbreak of West Nile virus infection in humans, Romania, July to October 2010. Euro Surveill 2011 16(2):pii=19762. 